\title{
Prevalence of five pharmacologically most important CYP2C9 and CYP2C19 allelic variants in the population from the Republic of Srpska in Bosnia and Herzegovina
}

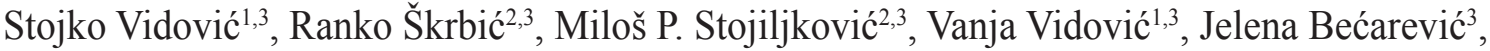 \\ Svjetlana Stoisavljević-Šatara ${ }^{2}$, and Nela Maksimovićc \\ ${ }^{1}$ University of Banja Luka Faculty of Medicine, Department of Human Genetics, Banja Luka, Bosnia and Herzegovina \\ ${ }^{2}$ University of Banja Luka Faculty of Medicine, Department of Pharmacology, Toxicology and Clinical Pharmacology, \\ Banja Luka, Bosnia and Herzegovina \\ ${ }^{3}$ University of Banja Luka Faculty of Medicine, Centre for Biomedical Research, Laboratory for Molecular Biology \\ and Genetics, Banja Luka, Bosnia and Herzegovina \\ ${ }^{4}$ University of Belgrade Faculty of Medicine, Institute of Human Genetics, Belgrade, Serbia
}

[Received in October 2020; Similarity Check in October 2020; Accepted in May 2021]

\begin{abstract}
The enzymes of the cytochrome P450 superfamily play a critical role in phase I drug metabolism. Among them, CYP2C9 and CYP2C19 are clinically important, as they can mediate severe toxicity, therapy failure, and increased susceptibility to cancer and other diseases caused by chemicals. The aim of this study was to determine the prevalence of pharmacologically most important allelic variants of the CYP2C9 and CYP2C19 genes in the general population of the Republic of Srpska (Bosnia and Herzegovina) and to compare them with other populations. For this purpose we determined the genotype profile and allele frequency of 216 randomly selected healthy volunteers using real-time polymerase chain reaction (RTPCR). The prevalence of the CYP2C9 *2 and *3 alleles was 13.6 and $7.4 \%$, respectively. Based on these frequencies, of the 216 participants four $(1.86 \%)$ were predicted to be poor metabolisers, $78(36.11 \%)$ intermediate, and the remaining $134(62.03 \%)$ normal metabolisers. Based on the prevalence of CYP2C19*2 and *17 variants -16.2 and $20.4 \%$, respectively - nine $(4.17 \%)$ were predicted to be poor, $57(26.39 \%)$ rapid, and nine $(4.17 \%)$ ultra-rapid metabolisers. We found no significant differences in allele frequencies in our population and populations from other European countries. These findings suggest that genetically determined phenotypes of $C Y P 2 C 9$ and $C Y P 2 C 19$ should be taken into consideration to minimise individual risk and improve benefits of drug therapy in the Republic of Srpska.
\end{abstract}

KEY WORDS: cytochrome P450 enzymes; pharmacogenetics; polymorphic allele

The cytochrome P450 (CYP) superfamily consists of enzymes with highly diverse roles in the metabolism of drugs, fatty acids, steroids, and xenobiotics $(1,2)$. Their genetic variants, single nucleotide polymorphisms (SNPs) in particular, can lead to therapy failure, severe toxicity, and increased susceptibility to cancer and other diseases caused by chemicals (3). CYPs make about $80 \%$ of all drug metabolising enzymes (DMEs), most notably those participating in phase I metabolism, such as flavincontaining monooxygenases, epoxide hydrolases, and many other oxidising, reducing, and hydrolysing enzymes (4).

Bearing in mind various types of mutation caused by SNPs, genotyping the most relevant CYP enzymes could identify patients at risk of developing adverse drug reactions and increase treatment safety and efficiency (3). In this respect, CYP enzymes CYP2C9 and CYP2C19 are among clinically most relevant, as they metabolise about 20-30\%

Corresponding author: Stojko Vidović, University of Banja Luka Faculty of Medicine, Department of Human Genetics, 78000 Banja Luka, Republic of Srpska, Bosnia and Herzegovina

E-mail:stojko.vidovic@med.unibl.org of all drugs (5). CYP2C9 metabolises over 100 drugs or about $15 \%$ of all drugs in current use $(6,7)$ including oral anticoagulants, nonsteroidal anti-inflammatory drugs, angiotensin II receptor antagonists, antidiabetic drugs, antiepileptics, and alkylating anticancer prodrugs (7-9). Clinically the most interesting allelic variants of CYP2C9 are $* 2$ and $* 3(10)$. The $* 2$ allele is categorised as a lossof-function variant, and the $* 3$ allele as a no-function variant, based on data obtained from studies conducted on multiple substrates, including flurbiprofen, celecoxib, phenytoin, and warfarin (9). Accordingly, an individual's ability to metabolise CYP2C9 substrates can be classified into the following phenotypes: normal metaboliser $(* 1 / * 1$ genotype), intermediate metaboliser $(* 1 / * 1 ; * 1 / * 3$; and $* 2 / * 2$ genotype), and poor metaboliser $(* 2 / * 3$ and $* 3 / * 3$ genotype) (11). Since the prevalence of poor metabolisers in Caucasian population is 3-5\%, genotyping of $C Y P 2 C 9 * 2$ and $* 3$ could be very important in initial dose adjustment in patients requiring anticoagulant therapy, such as warfarin $(12,13)$. 
CYP2C19 metabolises 8-10\% of commonly used drugs such as proton pump inhibitors, anticonvulsant drugs, antiplatelet drugs, and antidepressants $(14,15)$. Besides the wild-type $* 1$ allele, the most common allelic variant is the loss-of-function CYP2C19*2, characterised by reduced enzyme activity $(6,14)$. Its prevalence in European populations is $16 \%$, in Africa $14 \%$, and in Asia $26 \%$.

Genotyping for the CYP2C19 allelic variant $* 3$ is important in clinical practice, since its carriers have no ability to metabolise substrates completely, which may lead to drug accumulation in the body (16). Individuals carrying these two loss-of-function alleles (e.g. *2/*2, *2/*3, *3/*3) are therefore characterised as poor metabolisers (8). However, allelic variant $* 3$ is very rare in Europeans and Africans $(1 \%)$ but not as rare in Asians $(8 \%)(15,17)$.

In contrast to the $* 2$ allelic variant, a recently identified CYP2C19*17 variant increases transcriptional activity, and individuals carrying one wild-type (normal function) allele and one gain-of-function variant $(* 1 / * 17)$ are categorised as rapid metabolisers $(12,18)$, whereas those carrying two gain-of-function variants $(* 17 / * 17)$ are classified as ultrarapid metabolisers (19). Determining whether a person is a carrier of the $C Y P 2 C 19 * 17$ polymorphism could therefore be very important in clinical practice, since clopidogrel has increased efficacy in these carriers and increases their risk of bleeding $(14,20)$.

Considering that no genotyping of these important allele variants of CYP2C9 and CYP2C19 has been conducted in the Republic of Srpska in Bosnia and Herzegovina, the aim of our study was to fill that gap and also compare our findings with other populations.

\section{MATERIALS AND METHODS}

Our study included 216 randomly selected Caucasian healthy volunteers from the general population of the Republic of Srpska, which is one of the federal entities located in the northern and eastern part of Bosnia and Herzegovina, with a population of about 1.2 million (21). The sample was recruited to reflect population distribution from all over the Republic of Srpska. It consisted of 114 men (53\%) and 102 (47\%) women aged between 18 and 78 years (median: 41 ). The study was approved by the Ethics Committee of the University of Banja Luka Faculty of
Medicine. All participants signed informed consent forms before inclusion. The exclusion criteria were serious mental or physical illnesses. The study was performed according to the Declaration of Helsinki.

\section{Genotyping}

Genetic analysis was done at the Laboratory for Molecular Biology and Genetics of the University of Banja Luka Faculty of Medicine Center for Biomedical Research. Genomic DNA was extracted from $3-6 \mathrm{~mL}$ of peripheral blood collected in Na-EDTA tubes using PureLink ${ }^{\circledR}$ gDNA Blood Kit (Invitrogen, Carlsbad, CA, USA). Genotypes of CYP2C9 *2 (3608C > T, rs1799853), CYP2C9*3 (42164A >C, rs 1057910$), C Y P 2 C 19 * 2(681 \mathrm{G}>\mathrm{A}, \mathrm{rs} 4244285)$, CYP2C19*3 (17948G $>$ A, rs4986893), and CYP2C19*17 $(-806 \mathrm{C}>\mathrm{T}, \mathrm{rs} 12248560)$ were determined with real-time polymerase chain reaction (RT-PCR) using TaqMan ${ }^{\circledR}$ drug metabolism genotyping assays (C_25625805_10, C 27104892 10, C 25986767 70, C-469857 10, and C_27861809_10, respectively) according to the manufacturer's instructions (Applied Biosystems, Foster City, CA, USA). PCR conditions included initial denaturation/polymerase activation at $95{ }^{\circ} \mathrm{C}$ for $10 \mathrm{~min}$, followed by 50 two-step cycles: denaturation at $95{ }^{\circ} \mathrm{C}$ for $15 \mathrm{~s}$ and annealing and extension at $60{ }^{\circ} \mathrm{C}$ for $90 \mathrm{~s}$. The results were analysed with the Applied Biosystems 7500 software v2.0.6 (Applied Biosystems).

\section{Statistical analysis}

Allele and genotype prevalences were estimated by gene counting. Genotype distributions were tested for the HardyWeinberg equilibrium. Chi-squared test with Yate's correction was used to test similarities or differences in allele distribution. For all analyses we used the Social Science Statistics online calculators (https://www. socscistatistics.com/tests/).

\section{RESULTS AND DISCUSSION}

\section{CYP2C9}

As expected, the wild-type $C Y P 2 C 9 * 1$ dominated (78.90\%), followed by the CYP2C $9 * 2$ variant $(13.66 \%)$,

Table 1 Genotype and predicted phenotype prevalences of the $C Y P 2 C 9$ allelic variants in the population of the Republic of Srpska

\begin{tabular}{lcccc} 
Genotype & Participants (N) & Prevalence (\%) & $\begin{array}{c}\text { Confidence } \\
\text { interval }(\mathbf{9 5} \%)\end{array}$ & Predicted phenotype \\
\hline$C Y P 2 C 9 * 1 / * 1$ & 134 & 62.03 & $55.20-68.53$ & normal metabolisers \\
\hline$C Y P 2 C 9 * 1 / * 2$ & 47 & 21.76 & $16.45-27.86$ & intermediate metabolisers \\
\hline$C Y P 2 C 9 * 1 / * 3$ & 26 & 12.04 & $8.02-17.14$ & intermediate metabolisers \\
\hline$C Y P 2 C 9 * 2 / * 2$ & 5 & 2.31 & $0.76-5.32$ & intermediate metabolisers \\
\hline$C Y P 2 C 9 * 2 / * 3$ & 2 & 0.93 & $0.11-3.30$ & poor metabolisers \\
\hline$C Y P 2 C 9 * 3 / * 3$ & 2 & 0.93 & $0.11-3.30$ & poor metabolisers \\
\hline
\end{tabular}


Table 2 Genotype and predicted phenotype prevalences of the CYP2C19 allelic variants in the population of the Republic of Srpska

\begin{tabular}{lcccc} 
Genotype & Participants (N) & Prevalence (\%) & $\begin{array}{c}\text { Confidence } \\
\text { interval }(\mathbf{9 5} \%)\end{array}$ & Predicted phenotype \\
\hline$C Y P 2 C 19 * 1 / * 1$ & 89 & 41.20 & $34.57-48.08$ & normal metabolisers \\
\hline$C Y P 2 C 19 * 1 / * 2$ & 39 & 18.05 & $13.17-23.85$ & intermediate metabolisers \\
\hline$C Y P 2 C 19 * 2 / * 17$ & 13 & 6.02 & $3.24-10.07$ & intermediate metabolisers \\
\hline$C Y P 2 C 19 * 1 / * 3$ & - & - & - & intermediate metabolisers \\
\hline$C Y P 2 C 19 * 3 / * 17$ & - & - & - & intermediate metabolisers \\
\hline$C Y P 2 C 19 * 2 / * 2$ & 9 & 4.17 & $1.92-7.76$ & poor metabolisers \\
\hline$C Y P 2 C 19 * 3 / * 3$ & - & - & - & poor metabolisers \\
\hline$C Y P 2 C 19 * 2 / * 3$ & - & - & - & poor metabolisers \\
\hline$C Y P 2 C 19 * 1 / * 17$ & 57 & 26.39 & $20.64-32.80$ & rapid metabolisers \\
\hline$C Y P 2 C 19 * 17 * 17$ & 9 & 4.17 & $1.92-7.76$ & ultra-rapid metabolisers \\
\hline
\end{tabular}

while the prevalence of the $C Y P 2 C 9 * 3$ allele was $7.40 \%$ (Table 1). All observed genotype frequencies were in the Hardy-Weinberg equilibrium. Accordingly, the most prevalent $(62.03 \%)$ were normal metabolisers $(* 1 / * 1$ genotype). Poor metabolisers $(* 2 / * 3$ and $* 3 / * 3$ genotype) accounted for $1.86 \%$, and intermediate metabolisers $(* 1 / * 2$, $* 1 / * 3$ or $* 2 / * 2$ genotype) for $36.11 \%$ of participants.

The prevalences of $C Y P 2 C 9 * 2$ and $C Y P 2 C 9 * 3$ alleles found in our study are similar to the respective ones reported in other European countries such as Germany $(14.0 \%$; $\mathrm{p}=0.29$ and $5 \%$; $\mathrm{p}=0.37)(20)$, Russia $(10.5 \% ; \mathrm{p}=0.16$ and $6.7 \%$; $\mathrm{p}=0.78)(22)$, Spain $(16 \%$; $\mathrm{p}=0.36$ and $10 \% ; \mathrm{p}=0.25)$ (23), Greece (12.9 \%; $\mathrm{p}=0.80$ and $8.13 \% ; \mathrm{p}=0.58)$ (24), North Macedonia ( $13.9 \%$; $=0.91$ and $7.3 \%$; $p=0.94)(17)$, Croatia (14.5\%; $\mathrm{p}=0.65$ and $7.6 \% ; \mathrm{p}=0.89)(8)$, Serbia $(11.7 \% ; \mathrm{p}=0.30$ and $8.1 \% ; \mathrm{p}=0.68)(25)$, and Slovenia (12.2\%; $\mathrm{p}=0.54$ and $6.3 \% ; \mathrm{p}=0.55$ ) (26). However, one Romanian study (27) showed significantly higher prevalence of the $* 2$ and $* 3$ alleles $(29 \%, p<0.0001$ and $20.2 \%$; $<0.0001$, respectively). The general prevalences of the CYP $2 C{ }^{*} 2$ and $* 3$ alleles in the Caucasian population are about $13 \%(* 2)$ and $7 \%(* 3)(28)$ but significantly lower in the East Asians ( $0.01 \%$ and $0.3 \%$ ), Africans ( $2 \%$ and $1 \%)$, and African-Americans $(1 \%$ and $0.5 \%)(29,30)$. A more detailed comparison is available in Table 3.

\section{CYP2C19}

Again, the wild-type $C Y P 2 C 19 * 1$ allele was the most prevalent $(63.43 \%)$, followed by CYP 2 C19*2 $(16.20 \%)$ and $C Y P 2 C 19 * 17(20.37 \%)$ (Table 2). The observed prevalence of the $* 2$ and $* 17$ allelic variants were within the European ranges $(8,18)$. Similar prevalences have been reported for the neighbouring countries. In the Serbian population the prevalence of the $* 2$ allele was $16.3 \%$ $(\mathrm{p}=0.97)$ and of the $* 17$ allele $22.2 \%(\mathrm{p}=0.45)$. In the Croatian population it was $14.8 \%(\mathrm{p}=0.50)$ and $23.7 \%$ $(\mathrm{p}=0.19)$, in the North Macedonian $14.4 \%(\mathrm{p}=0.48)$ and $20.1 \%$ ( $\mathrm{p}=0.93$ ), and in the population of Kosovo $13.03 \%$ $(\mathrm{p}=0.18)$ and $19.01 \%(\mathrm{p}=0.61)$, respectively $(8,17,25,30)$. However, Russian and Greek studies showed a significant difference in the $* 2$ allele prevalence $(\mathrm{p}=0.0002$ and $\mathrm{p}=0.0035$, respectively) $(22,24)$. A more detailed comparison is given in Table 3 .

Eighty-nine participants $(41.20 \%)$ with the CYP 2 C $19 * 1 / * 1$ genotype were normal metabolisers, 52 $(24.07 \%)$ with the $C Y P 2 C 19 * 1 / * 2$ and $C Y P 2 C 19 * 2 / * 17$ genotypes were intermediate metabolisers, nine $(4.17 \%)$ with the $C Y P 2 C 19 * 2 / 2$ genotype were poor metabolisers, $57(26.39 \%)$ with the $C Y P 2 C 19 * 1 /{ }^{*} 17$ genotype rapid metabolisers, and nine $(4.17 \%)$ with the CYP $2 C 19 * 17 / * 17$ genotype were ultra-rapid metabolisers. Carriers of the CYP2C19*17 allele are at risk of bleeding, especially the ultra-rapid metabolisers (carriers of the CYP2C19*17/*17 genotype) (18). Carriers of the CYP2C19*2/*17 genotype are generally considered intermediate metabolisers, but their metabolic phenotype is difficult to predict, since some data suggest that $C Y P 2 C 19 * 17$ may not compensate for the CYP2C19*2 allele (8).

As for the CYP2C19*3 allele, none was detected in this study, which corresponds to other Caucasian populations such as Croatian, Danish, Canadian, German, Polish, and Australian (4, 31-35).

\section{CONCLUSION}

In summary, our data confirmed similar prevalences of the five CPY2C9 and CYP2C19 polymorphisms in the population of the Republic of Srpska with other European populations. Although our findings are based on a relatively small sample size, these data could be useful in assessing the risks and benefits of drug therapy in individuals requiring anticoagulant therapy, such as warfarin and clopidogrel.

\section{Conflict of interests}

None to declare. 


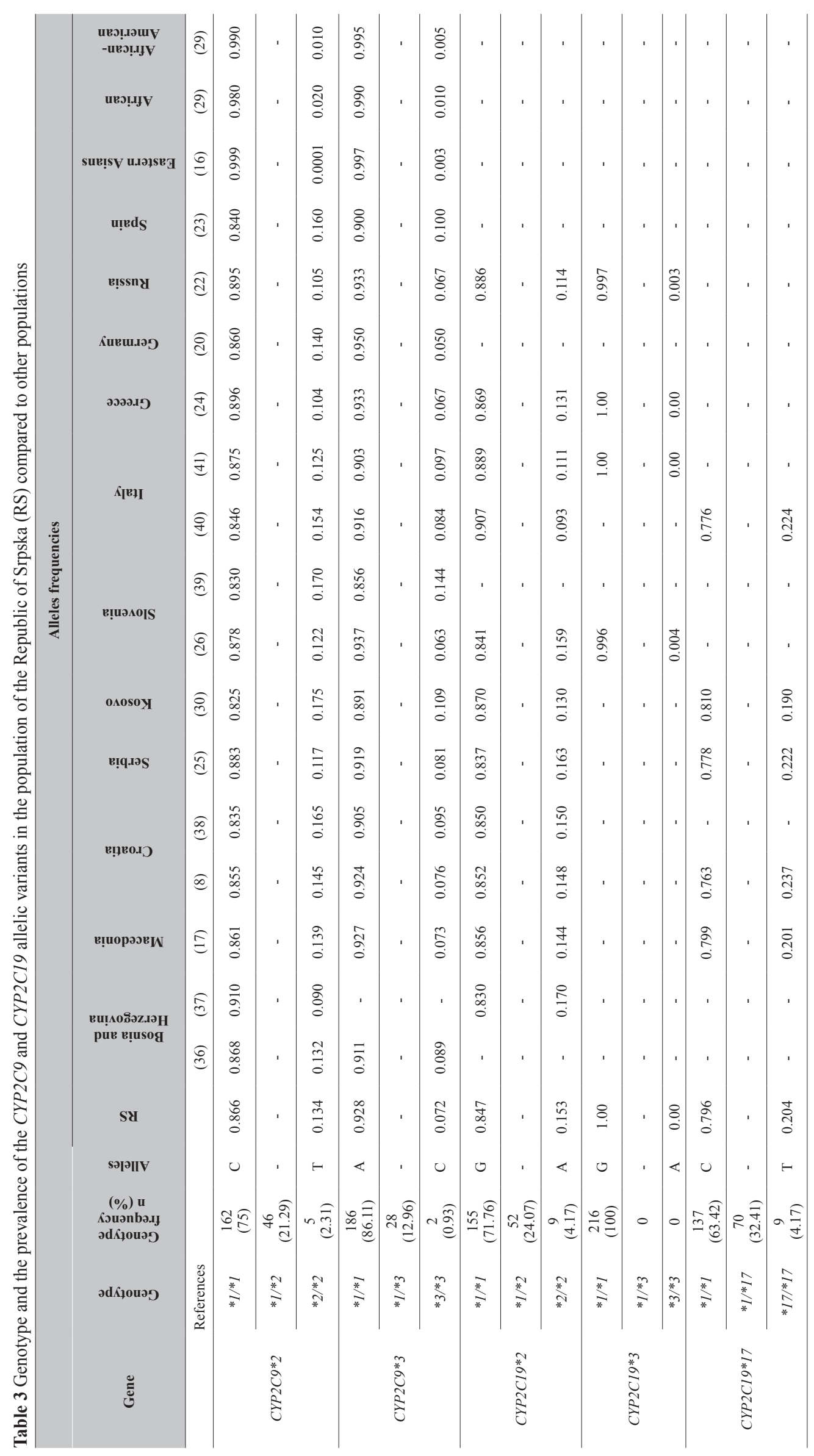




\section{REFERENCES}

1. Sim SC, Kacevska M, Ingelman-Sundberg M. Pharmacogenomics of drug-metabolizing enzymes: A recent update on clinical implications and endogenous effects Pharmacogenomics J 2013;13:1-11. doi: 10.1038/tpj.2012.45

2. Mustafa G, Nandekar PP, Bruce NJ, Wade RC. Differing membrane interactions of two highly similar drugmetabolizing cytochrome $\mathrm{P} 450$ isoforms: CYP 2C9 and CYP 2C19. Int J Mol Sci 2019;20:4328. doi: 10.3390/ijms20184328

3. Sim SC, Altman RB, Ingelman-Sundberg M. Databases in the area of pharmacogenetics. Hum Mutat 2011;32:526-31. doi: 10.1002/humu.21454

4. Raunio H. Modeling of interactions between xenobiotics and cytochrome P450 (CYP) enzymes. Front Pharmacol 2015;6:123. doi: 10.3389/fphar.2015.00123

5. Subramanian M, Agrawal V, Sandee D, Tam HK, Miller WL, Tracy TS. Effect of P450 oxidoreductase variants on the metabolism of model substrates mediated by CYP2C9.1, CYP2C9.2, and CYP2C9.3. Pharmacogenet Genomics 2012;22:590-7. doi: 10.1097/FPC.0b013e3283544062

6. Wu AHB. Drug metabolizing enzyme activities versus genetic variances for drug of clinical pharmacogenomic relevance. Clin Proteomics 2011;8:12. doi: 10.1186/15590275-8-12

7. Shirasaka Y, Chaudhry AS, McDonald M, Prasad B, Wong T, Calamia JC, Fohner A, Thornton TA, Isoherranen N, Unadkat JD, Rettie AE, Schuetz EG, Thummel KE. Interindividual variability of CYP2C19-catalyzed drug metabolism due to differences in gene diplotypes and cytochrome $\mathrm{P} 450$ oxidoreductase content. Pharmacogenomics J 2016;16:375-87. doi: 10.1038/tpj.2015.58

8. Ganoci L, Božina T, Mirošević Skvrce N, Lovrić M, Mas P, Božina N. Genetic polymorphisms of cytochrome P450 enzymes: CYP2C9, CYP2C19, CYP2D6, CYP3A4, and CYP3A5 in the Croatian population. Drug Metab Pers Ther 2017;32:11-21. doi: 10.1515/dmpt-2016-0024

9. Theken KN, Lee CR, Gong L, Caudle KE, Formea CM, Gaedigk A, Klein TE, Agúndez JAG, Grosser T. Clinical pharmacogenetics implementation consortium guideline (CPIC) for CYP2C9 and nonsteroidal anti-inflammatory drugs. Clin Pharmacol Ther 2020;108:191-200. doi: 10.1002/ cpt. 1830

10. Kirchheiner J, Brockmöller J. Clinical consequences of cytochrome P450 2C9 polymorphisms. Clin Pharmacol Ther 2005;77:1-16. doi: 10.1016/j.clpt.2004.08.009

11. Ingelman-Sundberg M, Sim SC, Gomez A, RodriguezAntona C. Influence of cytochrome $\mathrm{P} 450$ polymorphisms on drug therapies: Pharmacogenetic, pharmacoepigenetic and clinical aspects. Pharmacol Ther 2007;116:496-526. doi: 10.1016/j.pharmthera.2007.09.004

12. Šupe S, Poljaković Z, Božina T, Ljevak J, Macolić Šarinić V, Božina N. Clinical application of genotype-guided dosing of warfarin in patients with acute stroke. Arch Med Res 2015;46:265-73. doi: 10.1016/j.arcmed.2015.05.001

13. Shendre A, Dillon C, Limdi NA. Pharmacogenetics of warfarin dosing in patients of African and European ancestry. Pharmacogenomics 2018;19:1357-71. doi: 10.2217/pgs2018-0146

14. El Rouby N, Lima JJ, Johnson JA. Proton pump inhibitors: from CYP2C19 pharmacogenetics to precision medicine.
Expert Opin Drug Metab Toxicol 2018;14:447-60. doi: 10.1080/17425255.2018.1461835

15. Janha RE, Worwui A, Linton KJ, Shaheen SO, Sisay-Joof F, Walton RT. Inactive alleles of cytochrome P450 2C19 may be positively selected in human evolution. BMC Evol Biol 2014;14:71. doi: 10.1186/1471-2148-14-71

16. Dehbozorgi M, Kamalidehghan B, Hosseini I, Dehghanfard Z, Sangtarash MH, Firoozi M, Ahmadipour F, Meng GY, Houshmand M. Prevalence of the CYP2C19*2 (681 G>A), *3 (636 G>A) and *17 (-806 C>T) alleles among an Iranian population of different ethnicities. Mol Med Rep 2018;17:4195-202. doi: 10.3892/mmr.2018.8377

17. Jakovski K, Nestorovska AK, Labacevski N, Dimovski AJ. Characterization of the most common CYP2C9 and CYP2C19 allelic variants in the population from the Republic of Macedonia. Pharmazie 2013;68:893-8. PMID: 24380239

18. Hicks JK, Sangkuhl K, Swen JJ, Ellingrod VL, Müller DJ, Shimoda K, Bishop JR, Kharasch ED, Skaar TC, Gaedigk A, Dunnenberger HM, Klein TE, Caudle KE, Stingl JC. Clinical pharmacogenetics implementation consortium guideline (CPIC) for CYP2D6 and CYP2C19 genotypes and dosing of tricyclic antidepressants: 2016 update. Clin Pharmacol Ther 2017;102:37-44. doi: 10.1002/cpt.597

19. Hicks JK, Bishop JR, Sangkuhl K, Muller DJ, Ji Y, Leckband SG, Leeder JS, Graham RL, Chiulli DL, LLerena A, Skaar TC, Scott SA, Stingl JC, Klein TE, Caudle KE, Gaedigk A. Clinical pharmacogenetics implementation consortium (CPIC) guideline for CYP2D6 and CYP2C19 genotypes and dosing of selective serotonin reuptake inhibitors. Clin Pharmacol Ther 2015;98:127-34. doi: 10.1002/cpt.147

20. Burian M, Grösch S, Tegeder I, Geisslinger G. Validation of a new fluorogenic real-time PCR assay for detection of CYP2C9 allelic variants and CYP2C9 allelic distribution in a German population. Br J Clin Pharmacol 2002;54:518-21. doi: 10.1046/j.1365-2125.2002.01693.x

21. Republika Srpska I of S. Population estimates, annual rellease 2013-2019. 2020;158(20):1.

22. Gaikovitch EA, Cascorbi I, Mrozikiewicz PM, Brockmöller J, Frötschl R, Köpke K, Gerloff T, Chernov JN, Roots I. Polymorphisms of drug-metabolizing enzymes CYP2C9, CYP2C19, CYP2D6, CYP1A1, NAT2 and of P-glycoprotein in a Russian population. Eur J Clin Pharmacol 2003;59:30312. doi: $10.1007 / \mathrm{s} 00228-003-0606-2$

23. Dorado P, Berecz R, Norberto MJ, Yasar Ü, Dahl ML, LLerena A. CYP2C9 genotypes and diclofenac metabolism in Spanish healthy volunteers. Eur J Clin Pharmacol 2003;59:221-5. doi: 10.1007/s00228-003-0588-0

24. Arvanitidis K, Ragia G, Iordanidou M, Kyriaki S, Xanthi A, Tavridou A, Manolopoulos VG. Genetic polymorphisms of drug-metabolizing enzymes CYP2D6, CYP2C9, CYP2C19 and CYP3A5 in the Greek population. Fundam Clin P harmacol $2007 ; 21: 419-26$. do i : 10.1111/j.1472-8206.2007.00510.x

25. Skadrić I, Stojković O. Defining screening panel of functional variants of CYP1A1, CYP2C9, CYP2C19, CYP2D6, and CYP3A4 genes in Serbian population. Int J Legal Med 2019;134:433-9. doi: 10.1007/s00414-019-02234-7

26. Herman D, Dolžan V, Breskvar K. Genetic polymorphism of cytochromes P450 2C9 and 2C19 in Slovenian population. Zdr Vestn 2003;72:347-51.

27. Buzoianu AD, Militaru FC, Vesa ŞC, Trifa AP, Crişan S. The impact of the CYP2C9 and VKORC1 polymorphisms on 
acenocoumarol dose requirements in a Romanian population. Blood Cells Mol Dis 2013;50:166-70. doi: 10.1016/j. bcmd.2012.10.010

28. Sistonen J, Fuselli S, Palo JU, Chauhan N, Padh H, Sajantila A. Pharmacogenetic variation at CYP2C9, CYP2C19, and CYP2D6 at global and microgeographic scales. Pharmacogenet Genomics 2009;19:170-9. doi: 10.1097/ FPC.0b013e32831ebb30

29. Johnson JA, Caudle KE, Gong L, Whirl-Carrillo M, Stein CM, Scott SA, Lee MT, Gage BF, Kimmel SE, Perera MA, Anderson JL, Pirmohamed M, Klein TE, Limdi NA, Cavallari LH, Wadelius M. Clinical pharmacogenetics implementation consortium (CPIC) guideline for pharmacogenetics-guided warfarin dosing: 2017 update. Clin Pharmacol Ther 2017; 102:397-404. doi: 10.1002/cpt.668

30. Krasniqi V, Dimovski A, Bytyqi HQ, Eftimov A, Šimičevic L, Božina N. Genetic polymorphisms of CYP2C9, CYP2C19, and CYP3A5 in Kosovar population. Arh Hig Rada Toksikol 2017;68:180-4. doi: 10.1515/aiht-2017-68-2998

31. Bathum L, Andersen-Ranberg K, Boldsen J, Brøsen K, Jeune B. Genotypes for the cytochrome p450 enzymes CYP2D6 and CYP2C19 in human longevity. Role of CYP2D6 and CYP2C19 in longevity. Eur J Clin Pharmacol 1998;54:427_ 30. doi: $10.1007 / \mathrm{s} 002280050487$

32. Jurima-Romet M, Goldstein JA, LeBelle M, Aubin RA, Foster BC, Walop W, Rode A. CYP2C19 genotyping and associated mephenytoin hydroxylation polymorphism in a Canadian Inuit population. Pharmacogenetics 1996;6:329 39. doi: 10.1097/00008571-199608000-00006

33. Brockmöller J, Rost K, Gross D, Schenkel A, Roots I. Phenotyping of CYP2C19 with enantiospecific HPLC quantification of $\mathrm{R}$ and $\mathrm{S}$ mephenytoin and comparison with the intron4/exon5 G > A splice site mutation. Pharmacogenetics 1995;5:80-8. doi: 10.1097/00008571-199504000-00004

34. Kurzawski M, Gawrońska-Szklarz B, Wrześniewska J, Siuda A, Starzyńska T, Droździk M. Effect of CYP2C19*17 gene variant on Helicobacter pylori eradication in peptic ulcer patients. Eur J Clin Pharmacol 2006;62:877-80. doi: 10.1007/ s00228-006-0183-2

35. Hoskins JM, Shenfield GM, Gross AS. Relationship between proguanil metabolic ratio and CYP2C19 genotype in a Caucasian population. Br J Clin Pharmacol 1998;45:499504. doi: 10.1046/j.1365-2125.1998.00807.x

36. Ašić A, Salazar R, Storm N, Doğan S, Höppner W, Marjanović D, Primorac D. Population study of thrombophilic markers and pharmacogenetic markers of warfarin prevalence in Bosnia and Herzegovina. Croat Med J 2019;60:212-20. doi: $10.3325 / \mathrm{cmj} .2019 .60 .212$

37. Semiz S, Dujić T, Ostanek B, Prnjavorac B, Bego T, Malenica M. Analysis of CYP2C9*2, CYP2C19*2, and CYP2D6*4 polymorphisms in patients with type 2 diabetes mellitus. Bosn J BASIC Med Sci 2010;10:287-91. doi: 10.17305/ bjbms.2010.2662

38. Božina N, Granić P, Lalić Z, Tramišak I, Lovrić M, Stavljenić-Rukavina A. Genetic polymorphisms of cytochromes P450: CYP2C9, CYP2C19, and CYP2D6 in Croatian population. Croat Med J 2003;44:425-8. PMID: 12950145

39. Herman D, Locatelli I, Grabnar I, Peternel P, Stegnar M, Mrhar A, Breskvar K, Dolzan V. Influence of CYP2C9 polymorphisms, demographic factors and concomitant drug therapy on warfarin metabolism and maintenance dose. Pharmacogenomics J 2005;5:193-202. doi: 10.1038/sj. tpj.6500308

40. Arici M, Özhan G. CYP2C9, CYPC19 and CYP2D6 gene profiles and gene susceptibility to drug response and toxicity in Turkish population. Saudi Pharm J 2017;25:376-80. doi: 10.1016/j.jsps.2016.09.003

41. Scordo MG, Caputi AP, D'Arrigo C, Fava G, Spina E. Allele and genotype frequencies of CYP2C9, CYP2C19 and CYP2D6 in an Italian population. Pharmacol Res 2004;50:195-200. doi: 10.1016/j.phrs.2004.01.004

\section{Prevalencija pet farmakološki najznačajnijih CYP2C9 $\mathrm{i}$ CYP2C19 alelenih varijanti u populaciji Republike Srpske u Bosni i Hercegovini}

Citokrom P450 (CYP) visokopolimorfna je superobitelj enzima s ključnom ulogom u metabolizmu lijekova, masnih kiselina, steroida i ksenobiotika. U okviru spomenute skupine enzimi CYP2C9 i CYP2C19 prepoznati su kao klinički važni jer sudjeluju u prvoj fazi metabolizma lijekova te mogu dovesti do neadekvatnoga terapijskog odgovora, toksičnosti i pojave određenih bolesti. Cilj istraživanja je bio odrediti genotipove i prevalenciju alela u 216 nasumice odabranih zdravih ispitanika u populaciji Republike Srpske (Bosna i Hercegovina), te rezultate usporediti s drugim populacijama. Genotipovi enzima CYP2C9 i CYP2C19 određeni su metodom lančane reakcije polimeraze u realnom vremenu (eng. real-time $P C R$ ). Prema protokolu proizvođača, korištene su Taqman početnice i probe (engl. Taqman SNP genotyping assay). Kod CYP2C9, učestalosti alela *2 $\mathrm{i} * 3$ su 13,6 odnosno 7,4 \%. Od 216 sudionika, njih četvero $(1,86 \%)$ spori su metabolizatori, a većina njih $(62,03 \%)$ normalni metabolizatori. Sto se tiče CYP2C19, učestalosti alela *2 $\mathrm{i} * 17 \mathrm{su} 16,2$ odnosno $20,4 \%$. Od ukupnoga broja sudionika, njih devet (4,17 \%) spori su metabolizatori, njih 57 (26,39 \%) brzi metabolizatori, a devet je sudionika $(4,17 \%)$ okarakterizirano kao ultrabrzi metabolizatori. U usporedbi s podatcima o učestalosti genotipova i alelnih varijanti CYP2C9 i CYP2C19 u drugim europskim populacijama, dobiveni rezultati pokazali su veliku sličnost. Rezultati ovog istraživanja upućuju da bi određene terapije trebale uzeti u obzir utvrđene fenotipove $C Y P 2 C 9$ i $C Y P 2 C 19$ prilikom procjene individualnih rizika i dobrobiti primjene. 